\title{
Dogville: A Melting Pot of Different Disciplines
}

\section{Dr. Dina Abd El-salam}

Department of English Language and Literature, Faculty of Arts - University of Alexandria 


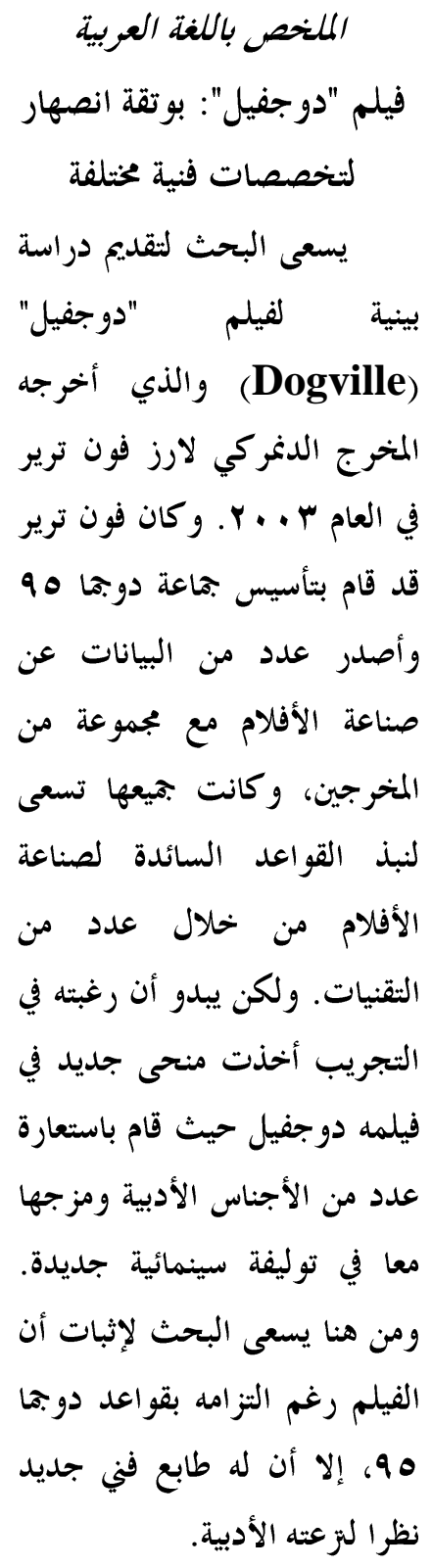

\section{Abstract}

Dogville: A Melting Pot of

\section{Different Disciplines}

The paper proposes to examine the interdisciplinary nature of the film Dogville, which was directed by the Danish director Lars von Trier in 2003. Co-founding Dogme 95 and issuing several Manifestoes on filmmaking, von Trier, along with a number of fellow filmmakers, seeks to repudiate mainstream filmmaking norms, through various techniques. In Dogville, however, his experimentation takes a new edge as he draws on different literary genres and amalgamates them into a new cinematic formulation. Thus, the paper seeks to prove that though Dogville largely observes the tenets of Dogme 95, it emerges as a new artistic formulation by virtue of its literary orientation.

Keywords:

Interdisciplinarity, Dogville, Lars von Trier, Dogme 95, New Wave, film, novel, drama, Bertolt Brecht. 


\section{Introduction}

We will no longer be satisfied with "well-meaning films with a humanist message", we want more-of the real thing, fascination, experience-childish and pure, like all real art. We want to get back to the time when love between filmmaker and film was young, when you could see the joy of creation in every frame of a film! (“DOGME 95 Manifesto" 1, 168)

In 1984, a group of Danish filmmakers issued a Manifesto to accompany the release of The Element of Crime, a film directed by the Danish filmmaker Lars von Trier. In this manifesto, they expressed their discontent with the coldness that has crept into the relationship between the filmmaker and his "film-wife", which according to them, has fallen into a "dull routine" and has turned into "a marriage of convenience" "DOGME 95 Manifesto" 1, 167). They expressed their wish to liberate movies from all preconceived expectations and to see instead "improbable, stupid, stubborn, ecstatic, repulsive, monstrous and not things that have been tamed or castrated by a moralistic, bitter old-filmmaker, a dull puritan who praises the intellect-crushing virtues of niceness" (168). 
Other manifestoes were to follow until "The Vow of Chastity" was finally released in 1995 to clearly establish the rules to be followed by the DOGME 95 brothers and their followers. The "Vow" starts with the following oath: "I swear to submit to the following set of rules drawn up and confirmed by DOGME 95" (171). Though it is no more than a filmic dogma, the use of religiously loaded words such as "vow", "chastity", "swear to submit" and "brothers" gives it a vocational dimension and the fact that the rules are ten in number, clearly evokes the Ten Commandments.

The rules chiefly state that shooting must be done on location without the use of sets and props; sound must be produced with the image and music must never be used, unless it emanates from the scene itself; the camera must be hand-held; special lighting, optical work and filters are not to be allowed and the director must not be credited.

In abiding by those rules, the Dogmers believe that artifice and premeditated design are checked or kept to a minimum as the filmmaker is cleansed from the corruptive and commercial turn that filmmaking has taken. 
Ties between Dogme 95 and the French New Wave:

Interestingly enough, the "Vow of Chastity" clearly severs any ties with the French New Wave (La Nouvelle Vague) which emerged in the sixties of the last century in France and is largely considered the precursor of alternative or independent cinema. Instead of creating thematically realistic movies through the use of ordinary people and subject matter, the New Wave tried to create technically realistic movies through the use of real settings, natural lighting and sound, improvised script and dialogue, long takes, hand-held cameras and jump cuts. All the theoretical formulations of this movement were pronounced in Les Cahiers du Cinema, which was founded in 1951 by André Bazin, Jacques Doniol-Valcroze and Joseph-Marie Lo Duca and to which Jean-Luc Godard, Claude Chabrol and François Truffaut, the main filmmakers of the movement, contributed frequently.

Despite the fact that much of what the "Vow of Chastity" states is a duplication of the tenets and principles that have been proposed earlier by Les Cahiers du Cinema and practised by all the New Wave filmmakers, Dogme 95 insists on detaching itself from 
the New Wave. In open criticism of the movement, "The Vow of Chastity" declares that, The new wave proved to be a ripple that washed ashore and turned to muck. Slogans of individualism and freedom created works for a while, but no changes. The wave was up for grabs, like the directors themselves. The wave was never stronger than the men behind it. The anti-bourgeois cinema itself became bourgeois, because the foundations upon which its theories were based was the bourgeois perception of art. The auteur concept was bourgeois romanticism from the very start and thereby...false! (170)

This criticism could be seen as no more than a filial rebellion against the domineering presence of the New Wave on the cinematic scene for a great deal of what Dogme 95 states and abides by is nothing but a rehash of the tenets of the New Wave. Hand-held cameras, long scenes, natural lighting and sound, violation of continuity editing and the 180-degree rule are sound proof of that. 


\section{Reasons why Dogville is a Dogme 95 film}

After this brief introduction to Dogme 95 and its connection with the New Wave, it remains yet to find out the characteristics which anchor Dogville in independent or alternative cinema.

As a movie, Dogville encapsulates much of what the Dogmers professed in their successive Manifestos and "Vow of Chastity". Firstly, it relies heavily on long takes, which von Trier uses to emulate the slow-paced, heavy-handed and at times suffocating movement of time. This technique also captures the intensity and immediacy of the moments as they unfold, hence fully engaging the spectator.

Secondly, von Trier shoots directly without rehearsals to capture the spontaneity and immediacy of the dramatic situations, a thing which was evident in Dogville Confessions, a documentary that captured the making of the movie through live footage, interviews, and confessions from participants in the film regarding their experience in a confession booth.

Moreover, the film is shot with hand-held cameras, or steadicams at best rate (as was evident in Dogville Confessions), which waver and shake along with the 
movement of the characters and action, hence emulating the constant change and flux of life, rather than the feigned stability that is projected onto films through the use of tripods and dollies.

Dogville, however, seems not to follow through all the rules of the "Vow of Chastity", for there is a musical score that intersperses the action of the film, hence clearly repudiating one of the basic tenets of the "Vow of Chastity". Moreover, credits, listing the full crew and cast, roll on screen at the end of the movie, which defies the rule that states that the director should not be credited. Jake Horsley also finds that the film clearly violates a number of other Dogme rules among which are location shooting as the film is shot on a set that is "partially constructed" so that it looks like a "backstage rehearsal in a giant warehouse" and is not shot on location, it also uses recorded narration, which violates the rule that states that sound must be an integral part of the image and not recorded in a studio, and it also makes extensive use of special lighting (13).

Von Trier has increasingly grown to violate the Dogme rules, which does not mean that his new films cease to belong to independent or alternative cinema. In effect, Linda Badley finds that "Dogville lacks the 
manifestos for which Trier has become notorious" (102) for "Dogville was its own manifesto" (103), and the reason would be its "unabashed theatrical and literary derivations" (105).

\section{Dogville's Literary Orientation}

Dogville rightly belongs to independent cinema not only because of all of the above-mentioned reasons, but also because of dappling into the literary arena, hence emerging as a uniquely experimental formulation.

\section{Affinities with the Novel:}

First, it has a glaring affinity with the novel as it is divided into a prologue and nine chapters. In fact, the film starts with: "The film Dogville as told in nine chapters and a prologue" and then, a black screen is projected, before the beginning of each section, with the title of the chapter and a short synopsis of it, which unfold as follows: The Prologue (which introduces us to the town and its residents); Chapter One "In which Tom hears gunfire and meets Grace"; Chapter Two "In which Grace follows Tom's plan and embarks upon physical labour"; Chapter Three "In which Grace indulges in a shady piece of provocation"; Chapter Four "Happy Times in Dogville"; ChapterFive "Fourth of 
July After all"; Chapter Six "In which Dogville bares its teeth"; Chapter Seven "In which grace finally gets enough of Dogville, leaves the town, and again sees the light of day"; Chapter Eight "In which there is a meeting in which the truth is told and Tom leaves (only to return later)" and Chapter Nine: "In which Dogville receives the long-awaited visit and the film ends".

The frequent appearance of black screens with chapter titles and short synopses, constantly interrupts the flow of the film to bring home to the spectator that he/she is watching a film with novelistic attributes. It is a technique which von Trier seems to have taken a particular liking to as he was to make use of it in a number of his movies, such as Breaking the Waves (1996), Manderlay (2005) and Antichrist (2009).

Another technique which von Trier heavily draws on in this film is that of narration. John Hurt's voice intersperses the movie as an omniscient narrator to explain or comment on the events. The telling technique is a novelistic mode of engagement, which originally pertains to stories, fables and romances, all of which predated the rise of the novel in the eighteenth century as a new literary genre. This novelistic technique immerses us into the fictional world of Dogville. 
It is noteworthy that the narration is poetically philosophical and densely packed with didactic comments, which is quite reminiscent of the highly moral purport of the novels of the eighteenth century. It also expresses deep cynicism towards the innate goodness of humanity and pinpoints the prevalence of evil and mercilessness in the world, a view which von Trier seems to adopt in many, if not most of his films.

In short, the division of Dogville into a prologue and nine chapters and the extensive use of omniscient narration strongly align it with the novel and clearly break the boundaries between film and the novel; the sacred space which each discipline traditionally inhabited is deconstructed, hence creating a slippery and elusive space between them, which allows for fluid exchange and interaction.

\section{Affinities with the Theatre:}

If the film is strongly affiliated with the novel, it also has strong affinities with the theatre. The actors are seen acting in settings that bring to mind theatrical sets; "theatrical" in the sense that the set is built to emulate reality but the audience can still tell it is not the real place. Similarly, in the theatre, the audience knows that the stage is not the real location but a semblance or 
at best a vraisemblance of it. Movies, by contrast, are shot on locations that greatly represent the real setting or at times on the very location itself. Badley finds that Dogville's "lack of cinematic verisimilitude makes active viewing, or reading, necessary, turning cinema into a "literary" experience" (104).

In fact, von Trier takes it even a step further as the houses, church, garden, shops are only distinguished by chalk borders and there are no walls or doors to separate them. To further distantiate the viewers from the setting, the names of the houses, streets and public places are written in chalk on the ground and the borders of each are clearly marked, hence constantly reminding them that this is an artificial set created by the filmmaker.

Obviously, this is a throwback to the Brechtian stage, which von Trier was heavily influenced by particularly during his formative years, as his mother used to take him regularly to Brecht's performances. Brecht, for instance, shunned the usage of lighting or special effects on stage, to avoid creating an illusory mood that would deceive the spectators into believing that what they were seeing on stage was real. In fact, if any lighting equipments were used, they were not 
hidden but left on stage to break the illusion of reality. In short, all of his sets bore a resemblance to reality but were never realistic.

In the same vein, von Trier creates a minimalist, skeletal, anti-illusionist mise-en-scène of an old American mining town, which has a strong affinity with Brecht's theatre.

As far as the content is concerned, Caroline Bainbridge finds that von Trier uses historicisation, very much like Brecht, to shed light on old sociopolitical themes which mirror contemporary ones:

Dogville, for instance, is set in the 1930s and yet its thematic content and the closing credit sequence are highly pertinent to contemporary life and to ideological and social concerns about globalization. Related anxieties about 'outsiders', discourses of immigration and the experience of exploitation, vengeance and social responsibility are all clearly evident themes. (6)

In short, Dogville's theatricality cannot be missed and its Brechtian overtones are glaringly evident to the extent that it could easily be considered a televised play rather than a movie. 


\section{Interdisciplinarity in Dogville}

Celestino Deletyo finds that the radical stylistic approach used in Dogville is an attempt by von Trier to, challenge what he considers reactionary attempts to cordon and limit film, theatre and literature. In Dogville, which is not an adaptation but based on an original script written by von Trier himself, and which employs an omniscient external narrator, he creates a fusion of the three arts. For von Trier, questions as to what is or is not filmic are irrelevant because in art everything is possible. (260)

Simply put, interdisciplinarity means "any form of dialogue or interaction between two or more disciplines" (Moran 16). Understandably, interdisciplinary modes are of a revolutionary nature; they are "adventurous and even transgressive" (Mitchell) since they, challenge traditional, outmoded systems of thought which are kept in place by institutional power structures; they can produce new, innovative theories and methodologies which open up the existing disciplines to new perspectives; they can help people to think more creatively about the relationship between their own subject and other ways of doing things. (Moran 182) 
Moran's words are to be easily understood in light of what the French philosopher Michel Foucault said about knowledge as being a by-product of power structures; disciplines and sciences such as psychiatry, psychology, medicine, and law studies, act in accordance with the dictates of power and are completely subservient to them. They, wittingly or unwittingly, reinforce the kind of order and stability that serves power structures. No wonder it is the theories of "French thinkers such as Foucault and Jacques Derrida- who express such strong hostility toward the construction of abstract and normative theories of human nature and conduct" (Reese), that were to forward interdisciplinarity.

Interestingly enough, Roland Barthes finds that interdisciplinarity is a violent act rather than a peaceful process as it initially originates to create a new grammar altogether, instead of the old decadent forms:

interdisciplinarity is not the calm of an easy security; it begins effectively [...] when the solidarity of the old disciplines breaks down- perhaps violently, via the jolts of fashion- in the interest of a new object and a new language neither of which has a place in the field of the sciences that were to be brought peacefully together, 
this unease in classification being precisely the point from which it is possible to diagnose a certain mutation (160).

In the same vein, Mitchell finds indiscipline to be a moment of "turbulence or incoherence", of "breakage or rupture", a "moment of chaos or wonder when a discipline, a way of doing things, compulsively performs a revelation of its own inadequacy". His words clearly pinpoint the violent and aggressive nature of interdisciplinarity.

Kostas Myrsiades sustains this argument about violence and argues that "interdisciplinarity demonstrates that place where the two disciplines have achieved a singularity of focus so that boundaries are busted and disciplinary paradigms are subordinated to the interests of a particular issue" (2).

Both arguments clearly show that interdisciplinarity usually entails a high degree of violence since it is all about breaking the old boundaries in an attempt to create a new space instead of the suffocating straitjackets of disciplines.

In von Trier's case, this violence emanates from his abhorrence of America's hegemony over the world 
which is furthered by the machinery of Hollywood, a machinery that is intent on creating set models and patterns for art and its consumption.

Von Trier's Political Stand and its Repercussions on his Art

Grace runs away from her father, a gangaster, as she abhors his lifestyle and seeks refuge in the town of Dogville. At first, the inhabitants agree to give her shelter in return for little services, but with the passage of time, she is mistreated, exploited, degraded and even sexually abused by all the male inhabitants of the town. When her father comes to fetch her, towards the end of the movie, and her true identity as the daughter of a boss of gangsters is revealed, the situation is reversed as she becomes in control of the fates of those who have mercilessly wronged her. At first, she considers forgiving them for their ill deeds are nothing but a symptom of their human weakness, but on second thoughts, she orders her men to annihilate them ruthlessly in order to rid the world of their evil.

The tragic fate of the townspeople of Dogville could be seen in different lights. One of them is 
definitely theological. In fact, John Collins compares their fate with that of the people of Amos:

The long-suffering heroine, Grace (played by Nicole Kidman), has a late and unexpected opportunity to turn the tables on the townspeople who have made her life miserable. At first, she is inclined to be merciful and forgiving. She thinks, we might say, of the faces of these people with whom she has lived and is inclined to overlook their faults. But then the moonlight grows clearer, and she sees that these faces do not inspire so much compassion after all. She also thinks of the possibility that other unfortunate people may wander into this town in the future and be subjected to abuse as she was. So she decides that it is her moral responsibility to improve the state of humanity, if only by a little, and has everyone in the town wiped out. (159)

Though this biblical comparison does hold a lot of substance and make a great deal of sense, it should not overshadow the overtly political dimension of the movie.

Generally speaking, von Trier is known to be against America's foreign policy which is motivated by pure self-interest rather than the so-called desire to 
spread peace and justice. Badley finds that "the newly armed and judgmental Grace becomes, among other probabilities, a caricature of the Bush administration's self-righteous militancy driven by misplaced idealism" (113) and its "War on Terror against an "Axis of Evil" " (102).

Von Trier is also against the proliferation of American images and models through the machinery of globalization, which is nothing but a manifestation of America's hegemony over the world. Ironically enough, these images are based on a "mythical past and sustained by Hollywood" (Badley 103).

The systematic extermination of the indigenous inhabitants of America, slavery, the Vietnam war, overt capitalism to name but a few, clearly shatter that mythical past or the so-called "American dream", the promised land of justice, peace, tolerance, equality and surplus, which is largely propogated by Hollywood. The end credits of Dogville, which are shown over a sequence of photos from the Depression-era Farm Security Administration photos to the anti-America song Young American by David Bowie, clearly declare his stand. 
Von Trier's films "contribute toward the undoing of the imagined community of the Hollywood audience, revealing it as a construct that is motivated by a mode of cultural imperialism that is designed to "democratise" a very particular rhetoric of industry, capital and media entertainment" (Bainbridge 135). In fact, he was not to stop at that for Dogville was to be the first film of a Trilogy that is called The USA: Land of Opportunities. It was followed by the "politically charged" (Jess-Coke 90) Manderlay (2005) and is yet to be followed by Washington.

Thus, the content of this film, which basically represents a sharp criticism of America's hegemony over the world, is best expressed in a form which is in keeping with it. In this case, the form clearly represents a departure from mainstream Hollywood filmmaking techniques and in fact, seeks to entirely deconstruct them, hence expressing von Trier's blatant and blunt anti-Americanism. His violent breaking of the boundaries that isolate disciplines, in addition to his anti-mainstream filming techniques, are in tune with his subject matter.

Interestingly enough, he casts one of Hollywood's stars (Nicole Kidman) in a film which defies 
Hollywood's concepts of filmmaking, which seems to be a tactical and strategic move on his part. Lars von Trier is a resilient and militant filmmaker. "He is not susceptible to temptation; he is not to be assimilated, ever, into any other agenda outside his own" (Horsley 12). He was not going to succumb to Hollywood and "so Hollywood would just have to come to him. This it finally did, in the alluring and delicate form of Nicole Kidman" (9).

\section{Interdisciplinarity questioned}

In his essay "Being Interdisciplinary is so very Hard to Do", Stanley Fish questions the validity of interdisciplinarity and finds that it is illusory. According to him, it is likely that one would invoke and refer to "the achievements, dicta, emphases, and requirements of other disciplines", but that does not mean that the boundaries have melted away and that the disciplines have peacefully merged into one whole. The reason being that:

the imported product will always have the form of its appropriation rather than the form it exhibits "at home"; therefore at the very moment of its introduction, it will already be marked by the 
discourse it supposedly "opens." When something is brought into a practice, it is brought in in terms the practice recognizes; the practice cannot "say" the Other but can only say itself, even when it is in the act of modifying itself by incorporating material hitherto alien to it. (107)

In other words, the sheer introduction of a discipline into another discipline instantly means that each of them is a discipline in its own right. Fish does not deny that institutional forces create rigid disciplines and that the lines "demarcating one field of study from another are not natural but constructed by interested parties who have a stake in preserving the boundaries that sustain their claims to authority" (100). In fact, he refers to this as a "legitimate thesis" but he finds that this legitimate thesis often leads to a misconception or "an illegitimate thesis":

An illegitimate inference that has been drawn from a legitimate thesis. The thesis is the one we began with: disciplines are not natural kinds; they emerge in the wake of a political construction of the field of knowledge. The illegitimate inference is that since disciplinary boundaries are constructed and revisable, they are not real. But of course they are as real as 
anything else in a world in which everything is constructed (the world posited by those who make this argument); even though the lines demarcating one discipline from another can in time blur and become rearranged, until that happens the arrangements now in force will produce differences felt strongly by all those who live within them. Although it is true that disciplines have no essential core (another way of saying that they are not natural kinds), the identity conferred on them by a relational structure - a structure in which everything is known by what it is not constitutes (however temporarily) a core that does all the work an essentialist might desire. (109)

Fish's words seem to come from a structuralist stance rather than a post-structuralist one since, like the structuralists, he finds that categories and disciplines have no essential core, only a relational character which emanates from a fabricated structure. These categories cannot be defined in isolation but come to have a meaning and existence in relation to other words, for they are mutually defining and constitutive. Accordingly, male is defined in relation to female, white in relation to black, heterosexual in relation to homosexual and so forth. This system of concepts which 
allows us to think in certain patterns, conventions and structures is largely fabricated by power. Emile Benveniste, a major structuralist, sums it all up: "The relativity of values is the best proof that they depend closely upon one another in the synchrony of a system which is always being threatened, always being restored" (48).

Post-structuralists, by contrast, find that categories, identities and structures at large are in a continuous state of flux and change, since they are a byproduct of language, which by definition is elusive and unstable, a stance which Stanley seems not to adopt in his essay "Being Interdisciplinary is so very Hard to Do".

Fish goes even further to assert that "the blurring of existing authoritative disciplinary lines and boundaries will only create new lines and new authorities" (106), which means that interdisciplinarity itself will turn into a new discipline; the lines will only be "redrawn" and "reconfigured" (106).

This thesis also emanates from a purely structuralist trajectory as it simply means that new structures will replace the old ones, for there always has to be a binding structure. 


\section{Interdisciplinarity stands the test of time}

Taking into consideration that the above article was written in 1989, interdisciplinarity seems to have stood the test of time, and to have played the ad hoc deconstruction game of casting a mist of instability on all traditional categories and distinctions.

The result of this breaking up of the rigid boundaries, which kept each discipline seemingly intact, was a profusion of interdisciplinarity. In fact, "every up-to-date university in the United States prides itself on its commitment to interdisciplinary research and training. Institutes, councils, consortia, collaborative groups, and workshops are set up to foster conversations across disciplines" (Mitchell).

Jenny Walklate and Adair Richards find that disciplines are real, a question which Fish adamantly asserted in his essay "Being Interdisciplinary is so very Hard to Do", at least since humans have fabricated them and continue to regard them as beneficial tools, but they also argue that they are not "fixed and immutable".

Instead of being enslaved to them, one should borrow ideas, tools and techniques from extant 
disciplines and fuse them together, as this leads to creativity (Strober 165) and the discovery of hitherto untrodden lands of innovation, instead of monotony and iteration.

Evoking a golden age, Moti Nissani reminds us of the all-rounders of the Renaissance and the unity of knowledge at that time,

By now, most of us no longer think it possible to become a Renaissance Scholar à la Leonardo da Vinci. Gradually during the nineteenth century, the ideal of the unity of knowledge--that a genuine scholar ought to be familiar with the sum total of humanity's intellectual and artistic output--gave way to specialization (202).

But the result of specilisation was unfavourable for, in his view, "those who stop at the disciplinary edge run the risk of tunnel vision" (Nissani 208). 


\section{Conclusion}

Contacts, exchanges and overlaps between the cinema, the novel and drama in Dogville produce a rich opus, which amalgamates the disciplines, hence revealing that they are not as esoteric and selfcontained as is often claimed. Through the use of crosspressure, the disciplines are forced to open up, and start flowing into one another, the result of which is harmony and co-existence rather than narrow compartmentalization and isolation.

The claim that interdisciplinarity is another form of disciplinarity, despite its viability, does not detract from the former's importance. One needs look no further than the motives of those who practice interdisciplinarity to know that they primarily seek to break free from conventions and fixed patterns, which by definition is transgressive and revolutionary. The fact that interdisciplinarity is turning into a discipline in its own right, seems more related to the mechanics of power which seek to contain subversion, in which case interdisciplinarity would be considered an eminent threat that should be bridled. 


\section{Works Consulted}

\section{Primary Sources:}

Antichrist. Dir. Lars von Trier. Screenplay by Lars von Trier. Zentropa Entertainments, 2009.

Breaking the Waves. Dir. Lars von Trier. Screenplay by Lars von Trier, Peter Asmussen \& David Pirie. Zentropa Entertainments, 1996.

Von Trier, Lars et al. "DOGME 95 Manifesto 1". The Cinema of Lars von Trier; Authenticity and Artifice. London: Wallflower Press, 2007. 167-168.

Dogville. Dir. Lars von Trier. Screenplay by Lars von Trier. Lionsgate, 2003.

Dogville Confessions. Dir. Sami Saif. A-Film Distribution, 2003.

The Element of Crime. Dir. Lars von Trier. Screenplay by Lars von Trier \& Niels Vørsel. Per Holst \& The Danish Film Institute, 1984.

Manderlay. Dir. Lars von Trier. Screenplay by Lars von Trier. Zentropa Entertainments, 2005. 
Von Trier, Lars et al. "The Vow of Chastity". The Cinema of Lars von Trier; Authenticity and Artifice. London: Wallflower Press, 2007. 171-172.

Secondary Sources:

Badley, Linda. Contemporary Film Directors: Lars von Trier. Urbana, Chicago, Springfield: University of Illinois Press, 2009.

Bainbridge, Caroline. The Cinema of Lars von Trier: Authenticity and Artifice. London: Wallflower Press, 2007.

Barthes, Roland. Image, Music, Text. Trans. Stephen Heath. London: Fontana Press, 1977.

Benveniste, Emile. Problems in General Linguistics. Trans. Mary Elizabeth Meek. Coral Gables: University of Miami Press, 1971.

Collins, John J. The Bible after Babel: Historical Criticism in a Postmodern Age. Grand Rapids: W. B. Eerdmans, 2005.

Deletyo, Celestino. "Me, Me, Me: Film Narrators and the Crisis of Identity". Books in Motion: Adaptation, Intertextuality, Authorship. Amsterdam: Rodopi, 2005. 243-262. 
Fish, Stanley. "Being Interdisciplinary is so very Hard to Do". MLA Profession 89, New York (1989): 1522.

Horsley, Jake. Dogville vs Hollywood: The War between Independent Film and Mainstream Movies. London: Marion Boyars, 2005.

Jess-Cooke, Carolyn. Film Sequels: Theory and Practice from Hollywood to Bollywood. Edinburgh: Edinburgh University Press, 2009.

Mitchell, W. J. T."Interdisciplinarity and Visual Culture". The Art Bulletin 77. 4 (1995).

Moran, Joe. Interdisciplinarity. New York: Routledge, 2001.

Myrsiades, Kostas. Un-Disciplining Literature: Literature, Law, and Culture. Ed. Linda Myrsiades. New York: Peter Lang, 1999.

Nissani, Moti. "Ten Cheers for Interdisciplinarity: The Case for Interdisciplinary knowledge and Research". The Social Science Journal 34.2 (1997) 201216.

Reese, Thomas F. "Mapping Interdisciplinarity". The Art Bulletin 77.4 (1995). 
Scheff, Thomas. "Getting Unstuck:

Interdisciplinarity as a New Discipline". Sociological Forun 28.1 (2013). 179-185.

Strober, Myra H. Interdisciplinary Conversations: Challenging Habits of Thought. Stanford: Stanford University Press, 2011.

Walklate, Jenny \& Adair Richards. "The Symbiotic Academy: On Specialisation and Interdisciplinarity". Science Progress 95.4 (2012). 